\title{
A Pharmacognostical and Phytochemical study of Sookshma Eladi Choornam
}

\author{
Research Article
}

\section{Harinatha Chary B1* ${ }^{*}$ Manu Rajagopal ${ }^{2}$, Pavan Kumar S33, Gnana Prasuna S1}

\author{
1. PhD scholar, 2. Professor, Department of Kayachikitsa, \\ Parul Institute of Ayurveda, Parul University, Vadodara, Gujarat India. \\ 3. Associate Professor, Department of Dravya Guna, \\ S.V.Ayurvedic College, TTD, Tirupati, India.
}

\begin{abstract}
Introduction: Sookshma Eladi choornam is one of the Ayurvedic formulations specially mentioned for Kaphaja Hridroga in Hridroga prakarana of Bhaishajya Ratnavali. Dhamani pratichaya (Atherosclerosis) is one of the diseases of Kaphaja nanatmaja vaydhi which is the more important cause for Ischemic Heart Disease. The cause for Atherosclerosis could be Hyperlipidemias. Eladi choornam is a compound preparation which contains powders of Sookshma ela (Elettaria cardamomum Maton.) and Pippali moolam (root of Piper longum L.,). As these drugs are Katu vipaka in nature they can be used in Hyerlipidemia. To know the efficacy of the drugs their quality parameters are highly essential to manufacture in the large scale. Method: The present study deals with the Pharmacognostical and phyto-chemical study of Sookshma eladi choornam including Thin Layer chromatography study (TLC) as per the standard literature. Result: Consistency of Sookshma eladi choornam is fine powder. Colour was brown, odour was aromatic spicy smell, Taste was pungent, touch was smooth powder form, Qualitative study showed that $\mathrm{pH}$ is 4.9, total ash value $12 \%$, loss on drying is $4.5 \%$, Water soluble matter $17 \%$, Alcohol soluble matter $8 \%$, Acid insoluble ash $8.5 \%$. Thin Layer chromatography (TLC) revealed one yellow spot. Dissolution time is 4 minutes and Moisture content was $8 \%$. Phytochemicals as Alkaloids, Glycosides, Tannins, Flavonoids and Phenols were found. Conclusion: Pharmacognostical, phyto-chemical and TLC studies inferred that the formulation meets the minimum quality standards. The study may be used as reference standard in the further quality control researches.
\end{abstract}

Key Words: Hirdroga, Hyperlipidemia, Dhamani Pratichaya, Atherosclerosis.

\section{Introduction}

Hyperlipidemia is defined as an elevation of one or more of the following in the blood: cholesterol, cholesterol esters, phospholipids, or triglycerides. Abnormalities of plasma lipids can result in predisposition to coronary, cerebrovascular, and peripheral vascular arterial diseases (1).

This is considered as one of the major risk factors for Cardiovascular diseases (CVDs). One third of the total deaths around the world are believed to be due to $\operatorname{CVDs}(2)$.

Hyperlipidemia is one of the major causes of atherosclerosis which is strongly related to the ischaemic heart disease (IHD). Atherosclerosis is a process in which arteries become hard due to deposition of cholesterol in their wall and cause narrowing of the arteries. In addition, hyperlipidemia along with oxidative stress may cause oxidative modifications in low-density lipoproteins, which play an important part in the initiation and development of atherosclerosis and related cardiovascular diseases (3).Lipid lowering drugs

\section{* Corresponding Author:}

\section{Harinatha Chary B}

$\mathrm{PhD}$ scholar, Department of Kayachikitsa,

Parul Institute of Ayurveda,

Parul University, Vadodara, Gujarat India.

Email Id: drbhnchary@gmail.com like fibrates, statins and other anti-lipidemic drugs reduce the hyperlipidemia but has minimum effect on the oxidative stress and also are not free from toxic side effects (4). World ethno-botanical information stated that a number of herbal medicines from plants and vegetables are used for controlling hyperlipidemia and related complications in patients (5).

Ayruvedic medicine, a natural based medicine system followed mainly in India and some other South Asian countries proposes to use the herbal and mineral based medicines for the effective reduction of the hyperlipidemia with minimal adverse effects. It deals with the treatment of the whole body by correcting the three major humors called as Vata, Pitta and Kapha. Many formulations are mentioned for the effective treatment of various ailments of the body.

Sookshma eladi choornam is one of the Ayurvedic preparations mentioned in Hridrogaprakarana of Bhavaprakasha indicated in Kaphaja hridroga. Kaphaja hridroga is similar in clinical features with the cardiovascular diseases. The etiological factors like excesive intake of the oily and heavy foods which increase kapha in the body also increase medo dhatu because of their similarities in their physical nature. They also lead to conditions like dhamani pratichaya. Dhamani pratichaya (atherosclerosis) is said to be one of the nanatmaja vikaras of Kapha where in accumulation of medodhatu is also seen in the srotas which cause depletion of 
circulation and nutrition the target tissue. The pathology and the symptoms of the dhamani pratichaya are having major similarities with the Atherosclerosis. Sookshma eladi choornam is one such Ayurvedic remedy which can be given in hyperlipidemia (kaphaja hridroga) to prevent atherosclerosis (dhamani pratichaya). This is a compound herbal preparation contains two herbal drugs 1. Sookshma ela (Elettaria cardamomum (L.) Maton) and 2. Pippali moolam (Piper longum L.). Both the ingredients are highly indicated for the treatment of both the conditions of atherosclerosis and hyperlipidemia. The Dipana, Pacana, Hridya and soola prashamana actions of both the drugs help to overcome the cardiovascular disorders.

Before proceeding to the clinical activity of the drug, it is important to authenticate the samples and to select the best possible raw drugs for the better clinical results. Hence the present study if planned to identify the raw material for its authenticity and also set some standard for the complete preparation.

\section{Aims and Objectives}

- To study the Pharmacognostical aspects of individual drugs used in the preparation of Sookshama eladi choornam.

- To study the Phyto-chemical aspects of individual drugs used in the preparation of Sookshma eladi choornam

- To compare the Pharmacognostical and Phytochemical results with the standard literature available.

\section{Materials and Methods}

Collection of the drug Sookshma eladi choornam: Ingredients have been collected from the local market of Tirupati and authenticated by the Dept. of Dravya Guna, S.V. Ayurvedic College, TTD, Tirupati, using the standard literature available from the Ayurvedic Pharmacopoeia of India. The ingredients and the part used are given in Table no.1.

Table No.1: Ingredients of Sookshma eladi choornam

\begin{tabular}{|l|l|l|l|l|} 
SI.No. & $\begin{array}{l}\text { Drug } \\
\text { Name }\end{array}$ & $\begin{array}{l}\text { Botanical } \\
\text { name }\end{array}$ & $\begin{array}{l}\text { Part } \\
\text { used }\end{array}$ & Ratio \\
\hline 1 & $\begin{array}{l}\text { Sookshma } \\
\text { ela }\end{array}$ & $\begin{array}{l}\text { Elettaria } \\
\text { cardamomum } \\
\text { (L.) Maton. }\end{array}$ & $\begin{array}{l}\text { Fruit } \\
\text { and } \\
\text { seeds }\end{array}$ & 1 part \\
\hline 2 & $\begin{array}{l}\text { Pippali } \\
\text { moolam }\end{array}$ & $\begin{array}{l}\text { Piper longum } \\
\text { L. }\end{array}$ & Root & 1 part \\
\hline
\end{tabular}

Method of Preparation of Sookshma eladichoornam Ingredients enlisted in Table 1 are procured from the local market of Tirupati and are dried well in shade. After complete drying the ingredients (Sookshma ela and Pippali moola) are powdered individually in a grinder and sieved to collect the fine powder. They are then taken in equal quantities (1:1 ratio) and mixed together to make a homogenous mixture. For clinical application the medicine was manufactured in a bulk quantity by the Sahasrayoga Pharmacy in a single batch with batch no : SYSEC 1, manufacturing date: JULY 2019, Expiry date : JUNE 21, Licence no:T2122/AYUR.

The powder was analyzed using various standard physicochemical parameters as per Ayurvedic Pharmacopoeia of India (API) at the Varun Herbals Research and Testing Lab, Hyderabad, Telangana.

\section{Observations and Results}

The drugs were observed for their morphological and microscopic characters and are compared as per the Ayurvedic Pharmacopoeia of India.

\section{Morphological and microscopic observations of ingredients of Sookshma eladi choornam \\ Ela:}

Samples of ela fruit showed the morphological characters like long ovoid shape around $2 \mathrm{cms}$ long, greenish in colour, three sided containing around 4 seeds in three chambers accounting to around 12-15 seeds in a fruit. The seeds are dark brown to black, aromatic and have characteristic taste. Microscopic section of the seeds showed outer epidermis with thick walled cells. Parenchyma contained volatile oil in rectangular cells. Many rounded polyhedral starch grains are observed.

\section{Plate.1}

Section of the

TS of the Seed seed enlarged showing various

Section of the fruit coat layers
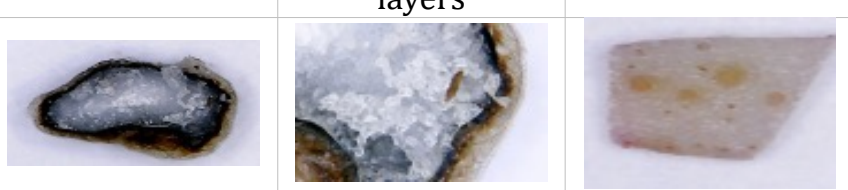

\section{Pippali moola:}

Transverse section of the root of Piper longum $L$. showed outermost cork as a narrow strip followed by wide parenchymatous cortex. Starch grains, oxalate crystals and secretory cells are observed. Central pith is observed around which four radiating strips of the vascular bundles are observed.

\section{Plate.2}

TS with cruciate shaped vascular bundles

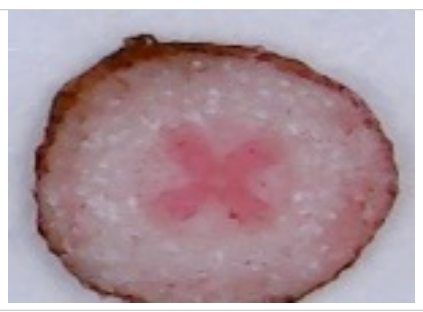

Enlarged view - xylem

vessles, outer undifferentiated paranchymatous cells

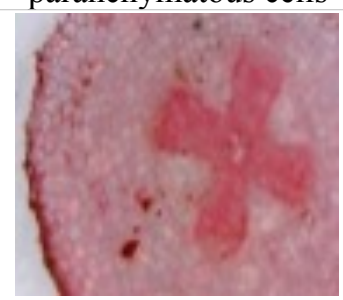

\section{Organoleptic parameters}

Organoleptic parameters(6)like, Colour, odour, taste and touch were scientifically studied and results were depicted in the table no.2. 
Table. No. 2: Organoleptic properties of Sookshma eladi choornam

\begin{tabular}{l|l|} 
Odor & Aromatic spicy smell \\
\hline Colour & Brown \\
\hline Touch & Smooth \\
\hline Consistency & Fine powder \\
\hline Taste & Pungent \\
\hline
\end{tabular}

Physico-chemical analysis:

Physicochemical parameters of Sookshma eladi choornam like Uniformity of the weight, Loss on drying, $\mathrm{pH}$, Ash Value, Water soluble extract, Methanol soluble extract, Acid insoluble ash, TLC was evaluated. The results are depicted at Table no.3.

Table No.3. Physico-Chemical investigations of Sookshma ela

\begin{tabular}{|l|l|l|l|l|}
\hline $\begin{array}{l}\text { S, } \\
\text { No. }\end{array}$ & Investigation & $\begin{array}{l}\text { API /AFI } \\
\text { Standards }\end{array}$ & $\begin{array}{l}\text { Test } \\
\text { results }\end{array}$ & Reference \\
\hline 1 & $\begin{array}{l}\text { Foreign } \\
\text { matter }\end{array}$ & Nill & Complies & AFI-2.2.2 \\
\hline 2 & $\begin{array}{l}\text { Total ash } \\
\text { Not more }\end{array}$ & $\begin{array}{l}\text { Non } \\
\text { than } 6 \%\end{array}$ & AFI-2.2.3 \\
\hline 3 & $\begin{array}{l}\text { Acid } \\
\text { insoluble ash }\end{array}$ & $\begin{array}{l}\text { Not more } \\
\text { than } 4 \%\end{array}$ & $3.82 \%$ & AFI-2.2,4 \\
\hline 4 & $\begin{array}{l}\text { Alcohol } \\
\text { soluble } \\
\text { extractive }\end{array}$ & $\begin{array}{l}\text { Not less } \\
\text { than } 2 \%\end{array}$ & $2.32 \%$ & AFI-2.2.6 \\
\hline 5 & $\begin{array}{l}\text { Water soluble } \\
\text { extractive }\end{array}$ & $\begin{array}{l}\text { Not less } \\
\text { than } 10 \%\end{array}$ & $11.2 \%$ & AFI-2.2.7 \\
\hline 6 & Volatile oil & $\begin{array}{l}\text { Not less } \\
\text { than } 4 \%\end{array}$ & $4.32 \%$ & AFI-2.2.10 \\
\hline
\end{tabular}

Table No.4. Physico-Chemical investigations of Pippali moola

\begin{tabular}{|c|c|c|c|c|}
\hline $\begin{array}{l}\text { S, } \\
\text { No. }\end{array}$ & Investigation & $\begin{array}{l}\text { API /AFI } \\
\text { Standards }\end{array}$ & $\begin{array}{l}\text { Test } \\
\text { results }\end{array}$ & Reference \\
\hline 1 & $\begin{array}{l}\text { Foreign } \\
\text { matter }\end{array}$ & Nill & Complies & AFI-2.2.2 \\
\hline 2 & Total ash & $\begin{array}{l}\text { Not more } \\
\text { than } 6 \%\end{array}$ & $6 \%$ & AFI-2.2.3 \\
\hline 3 & $\begin{array}{l}\text { Acid } \\
\text { insoluble ash }\end{array}$ & $\begin{array}{l}\text { Not more } \\
\text { than } 4 \%\end{array}$ & $3.82 \%$ & AFI-2.2,4 \\
\hline 4 & $\begin{array}{l}\text { Alcohol } \\
\text { soluble } \\
\text { extractive }\end{array}$ & $\begin{array}{l}\text { Not less } \\
\text { than } 2 \%\end{array}$ & $2.32 \%$ & AFI-2.2.6 \\
\hline 5 & $\begin{array}{l}\text { Water soluble } \\
\text { extractive }\end{array}$ & $\begin{array}{l}\text { Not less } \\
\text { than } 10 \%\end{array}$ & $11.2 \%$ & AFI-2.2.7 \\
\hline 6 & Volatile oil & $\begin{array}{l}\text { Not less } \\
\text { than } 4 \%\end{array}$ & $4.32 \%$ & AFI-2.2.10 \\
\hline
\end{tabular}

Table No.5: Physico-chemical parametersof Sookshma eladi choornam

\begin{tabular}{|l|l|l|l|l|}
\hline S.No & Test Parameters & $\begin{array}{l}\text { Method/ } \\
\text { SOP No. }\end{array}$ & Results & $\begin{array}{l}\text { Unit of } \\
\text { measure } \\
\text { ment }\end{array}$ \\
\hline $\mathbf{1}$ & Loss of drying & API & 4.5 & $\%$ \\
\hline 2 & Water soluble matter & API & 1.7 & $\%$ \\
\hline 3 & Alcohol soluble matter & API & 8 & $\%$ \\
\hline 4 & Total ash & API & 12 & $\%$ \\
\hline 5 & Acid insoluble ash & API & 8.5 & $\%$ \\
\hline 6 & PH & API & 4.9 & - \\
\hline
\end{tabular}

\section{Thin layer chromatography study:}

TLC study was carried out by VHIP method using Toulene and Ethyl acetate (9:1) during the mobile phase and Silica gel during the stationary phase. Vanillin and $\mathrm{H}_{2} \mathrm{SO}_{4}$ reagent was the spraying agent used for the TLC Study. The chromatograph showed one spot at $\mathrm{Rf} 0.18$ (Yellow). Rf values of the spot obtained was at a comparable level which indicates the presence of some definite constituents in the sample.

Table No.6: Results of TLC of Sookshma eladi choornam

\section{Plate.3: TLC \\ Study of \\ Sookshma \\ Eladi \\ Choornam}

\begin{tabular}{|c|c|c|c|}
\hline Method & \multicolumn{2}{|l|}{ VHIP method } & \\
\hline Reagent & \multicolumn{2}{|c|}{ Vanillin and $\mathrm{H}_{2} \mathrm{SO}_{4}$} & \\
\hline \multirow[t]{2}{*}{ Solvent } & Mobile phase & $\begin{array}{l}\text { Toulene and } \\
\text { Ethyl acetate } \\
(9: 1)\end{array}$ & \\
\hline & $\begin{array}{l}\text { Stationary } \\
\text { phase }\end{array}$ & Silica gel & \\
\hline Bands & \multicolumn{2}{|l|}{ One spot } & \\
\hline Rf values & \multicolumn{2}{|l|}{0.18 (Yellow) } & 0 \\
\hline
\end{tabular}

Phytochemical screening of Sookshma ela, Pippali moola and Sookshma eladi choornam

Sookshma ela, Pippali moola and the finished drug Sookshma eladi choornam aqueous and alcohol extracts were subjected to phytochemical analysis to analyse the presence of various phytochemicals as flavonoids, saponins, amino acids, phenols, alkaloids, tannins, terpenoids, quinone and glycoside as per the following protocols:

i. All the three sample solutions were treated with $10 \% \mathrm{NaOH}$. Formation of greenish brown colour indicates the presence of flavonoids

ii. (Froth test):Each of the three sample solutions added to water and shaken well. Formation of froth indicates the presence of saponin.

iii. Each of the three sample solutions were boiled with $0.2 \%$ ninhydrin solution. Formation of purple colour indicates the presence of free amino acids .

iv. Each of the three sample solutions were treated with alcohol and ferric chloride. Formation of greenish yellow colour indicates the presence of phenols

v. $1 \mathrm{ml}$ of each test solution was treated with $1 \mathrm{ml}$ of Hagger's reagent. Formation of yellow colour precipitate indicates the presence of alkaloid

vi. : Each of the three sample solutions were treated with $20 \%$ boiled water and $0.1 \% \mathrm{FeCl} 3$. Formation of brownish green colour indicates the presence of tannin 
vii. Each of the three sample solutions were treated with chloroform and conc. H2SO4. Formation of orange colour indicates the presence of terpenoids

viii.: Each of the three sample solutions were treated with $\mathrm{HCl}$. Formation of a red precipitate indicates the presence of quinone.

ix. Each of the three sample solutions were treated with $2 \mathrm{ml}$ of glacial acetic acid containing few drops of $\mathrm{FeCl} 3$ and $1 \mathrm{ml} \mathrm{H} 2 \mathrm{SO} 4$ added. Formation of a brown layer at interfere indicates glycoside

\section{Table No:7. Phytochemical analysis of Sookshma} ela, Pippali moola and Sookshma eladi choornam

\begin{tabular}{|l|l|l|l|l|}
\hline $\begin{array}{l}\text { S. } \\
\text { No }\end{array}$ & Components & $\begin{array}{l}\text { Sookshma } \\
\text { ela }\end{array}$ & $\begin{array}{l}\text { Pippali } \\
\text { moola }\end{array}$ & $\begin{array}{l}\text { Sookshma } \\
\text { eladi } \\
\text { choornam }\end{array}$ \\
\hline 1 & Flavonoids & + & + & + \\
\hline 2 & Saponins & + & + & - \\
\hline 3 & Aminoacids & + & + & + \\
\hline 4 & Phenols & - & + & + \\
\hline 5 & Alkaloids & - & + & + \\
\hline 6 & Tannins & - & + & + \\
\hline 7 & Terpenoids & + & + & + \\
\hline 8 & Quinones & - & - & - \\
\hline 9 & Glycoside & + & - & + \\
\hline
\end{tabular}

\section{Discussion}

Phytochemical and pharmacognostical evaluation of Sookshma eladi choornam showed the specific characters of all the ingredients which were used in the preparation. The enlarged transverse section of seed of Sookshma ela (plate.1) showed outer thick walled epidermis followed by parenchymal layer of cells. The inner epidermis is thin walled with an inner integument and outer sclerenchyma (7). The phytochemical analysis of Sooksham ela showed the presence of flavonoids, saponins, amino acids, triterpinoids and glycosides. The transverse section of pippali moola showed (plate.2) cruciate shaped vascular bundles. The enlarged transverse section of pippali moola showed xylem vessels and outer undifferentiated parenchymatous cells (8). The phytochemical analysis of pippali moola showed the presence of flavonoids, saponins, amino acids, phenols, alkaloids, tannins and terpenoids.The Phytochemical analysis of Sookshma eladi choornam showed flavonoids, amino acids, phenols, alkaloids, tannins, terpinoids and glycosides. Physico-chemical analysis of Sookshma eladi choornam showed that $\mathrm{pH}$ was 4.9 ; total ash value $12 \%$, loss on drying was $4.5 \%$, Water soluble matter $17 \%$, Alcohol soluble matter $8 \%$, Acid insoluble ash $8.5 \%$. Thin Layer chromatography (TLC) revealed one yellow spot (plate.3). Dissolution time was 4 minutes and Moisture content was $8 \%$. After the preparation of Sookshma eladi choornam all the phytochemicals were found except saponins.

\section{Conclusion}

The ingredients of Sookshma eladi choornam were identified and authenticated pharmacognostically and were used for the preparation. The ingredients taken were pharmacognostically authentic in comparison with the standard literature available. The phytochemicals present in the individual drugs were present in the compound formulation which is evident from the phytochemical study except for the quinones and saponins. Thus this pharmacognostical study of Sookshma eladi choornam will help for further standardization of the medicine with more latest parameters.

\section{References}

1. Wells GB, Dipiro J, Schwinghammer T, Hamilton C. Pharmacotherapy Handbook, 7th Edn, The Mcgraw Hill Companies, USA, 2007; 98-108.

2. Ginghina, C., Bejan, I.,Ceck, C. D. Modern risk stratification in coronary heart disease.J. Med. Life., 2011; 4(4): 377-86.

3. Dahanukar SA, Kulkarni RA, Rege NN. Pharmacology of medicinal plants and natural products. Indian J Pharmacol 2000; 32: S81-S118.)

4. Sircar NON. Pharmacological basis of Ayurvedic therapy. In: Atal CK, Kapoor BM, editors. Cultivation and Utilization of Medicinal Plants. New Delhi, India: Publication and Information Directorate, CSIR; 1992: 507-518.

5. Sklar IV, Kakkar KK, Chakre OJ. Glossary of Indian Medicinal Plants With Active Principles. New Delhi: CSIR; 1992: 75.

6. Kokate CK, Purohit AP, Gokhale SB. Pharmacognosy. 42nd ed. Pune: Nirali Prakashan; 2008; 102 .

7. Ayurvedic Pharmacopoeia of India,Govt.ofIndia,Ministry of health and family welfare, dept.ofAYUSH,NewDelhi, partI, vol.I, first edition, p. 174

8. Ayurvedic Pharmacopoeia of India,Govt.of India, Ministry of health and family welfare, dept.ofAYUSH, NewDelhi, partI, vol.II, first edition, p.199. 